\author{
Z.B. Balgabayeva* (iD), L.A. Medukhanova \\ Al-Farabi Kazakh National University, Kazakhstan, Almaty, \\ *e-mail: zzelkowa@gmail.com
}

\title{
Social aspects of increasing environmental efficiency in Kazakhstan cities
}

\begin{abstract}
Within the framework of the environmental efficiency system, the authors consider such topical social factors for increasing environmental efficiency in Kazakhstan as the quality of environmental education, motivational mechanisms for regulating the problems of sorting secondary raw materials. It is noted that work with the population is becoming colossal in solving environmental problems. The foundations of the urban system and social management in the field of environmental development testify to the serious problem of waste recycling and disposal in Kazakhstan. The authors highlight several eco-projects that help to solve these issues, such as Kazakhstan Waste Recycle, Tazalyk and SMEs that accept recyclable materials, but the figures for unrefined waste in Kazakhstan indicate that the problem is systemic and alarming. As a solution, in addition to the applicable penalties, the authors propose the launch of multi-vector motivational programs integrated into the everyday life of citizens. Such programs are designed to be informative, educational in nature in addition to motivational; they must be scaled up and involve business representatives widely used in the fast moving consumer goods market. It is recommended to give these programs an image republican character to create resonant recognition and use. The paper analyzes the awareness, involvement of the local population in the issues of environmental recycling and waste disposal based on an online survey, and presents a consolidated program for motivating the population. The authors consider the prerequisites for the implementation of these programs, their main characteristics, goals and performance indicators.
\end{abstract}

Key words: waste sorting, waste recycle, green economy, motivation program, ecology.

$$
\begin{gathered}
\text { 3.Б. Балғабаева*, Л.Ә. Медуханова } \\
\text { Әл-Фараби атындағы Қазақ ұлттық университеті, Қазақстан, Алматы қ. } \\
\text { *e-mail: zzelkowa@gmail.com }
\end{gathered}
$$

Қазақстан қалаларында қоршаған ортаның тиімділігін арттырудың әлеуметтік аспектілері

Экологиялық тиімділік жүйесі шеңберінде авторлар Қазақстандағы экологиялық тиімділікті арттырудың өзекті әлеуметтік факторларын экологиялық білім берудің сапасы, екінші шикізатты сұрыптау мәселелерін реттеудің мотивациялық тетіктері ретінде қарастырады. Экологиялық мәселелерді шешуде халықпен жұмыс ауқымды бола түсетіні атап өтілді. Қалалық жүйенің және қоршаған ортаны дамыту саласындағы әлеуметтік менеджменттің негіздері Қазақстандағы қалдықтарды қайта өңдеу және жоюдың күрделі проблемалары туралы куәландырады. Авторлар осы мәселелерді шешуге көмектесетін бірнеше экологиялық жобаларды атап көрсетеді, мысалы, Қазақстан қалдықтарын қайта өңдеу, Тазалық және қайта өңдеуге болатын материалдарды қабылдайтын ШОК, бірақ Қазақстандағы қайта өңделмеген қалдықтардың көрсеткіштері бұл мәселенің жүйелі және үрей тудыратындығын көрсетеді. Шешім ретінде қолданыстағы айыппұлдардан басқа, авторлар азаматтардың күнделікті өміріне интеграцияланған көпвекторлы мотивациялық бағдарламаларды іске қосуды ұсынады. Мұндай бағдарламалар мотивациядан басқа ақпараттық, білімдік сипатта болады; олар кеңейтілген және тұтынушылық тауарлар нарығында кең қолданылатын бизнес өкілдерін қамтуы керек. Бұл бағдарламаларға резонансты тану және пайдалану үшін имиджге республикалық сипат беру ұсынылады. Жұмыста онлайн-сауалнама негізінде қоршаған ортаны қайта өндеу және қалдықтарды жою мәселелеріне жергілікті тұрғындардың хабардарлығы, қатысуы талданады, сонымен қатар тұрғындарды ынталандырудың шоғырландырылған бағдарламасы ұсынылған. Авторлар аталған бағдарламаларды іске асырудың алғышарттарын, олардың негізгі сипаттамаларын, мақсаттары мен нәтижелік көрсеткіштерін қарастырады.

Түйін сөздер: қалдықтарды сұрыптау, қалдықтарды қайта өңдеу, жасыл экономика, мотивациялық бағдарлама, экология.

\section{З.Б. Балгабаева*, Л.А. Медуханова}

Казахский национальный университет имени аль-Фараби, Казахстан, г. Алматы,

*e-mail: zzelkowa@gmail.com

\section{Социальные аспекты повышения экологической эффективности в городах Казахстана}

В рамках системы экологической эффективности авторами рассматриваются такие актуальные социальные факторы повышения экологической эффективности в Казахстане, как качество экологического образования, мотивационные механизмы регулирования проблем сортировки вторичного сырья. Отмечается, что работа 
с населением приобретает колоссальное значение в решении проблем экологии. Основы урбанистической системы и социального управления в области экологического развития свидетельствуют о серьезной проблеме вопросов переработки и утилизации отходов в Казахстане. Авторы выделяют несколько экопроектов, которые помогают решать данные вопросы, такие как Kazakhstan Waste Recycle, Tazalyk и предприятия МСБ, которые принимают вторсырье, однако цифры по не переработанным отходам в Казахстане говорят о том, что проблема носит системный характер и тревожную динамику. В качестве решения, помимо применяемых штрафных санкций, авторами предлагается запуск многовекторных мотивационных программ, интегрированных в повседневную жизнь граждан. Подобные программы призваны носить осведомительный, образовательный характер помимо мотивационного; они должны быть масштабированы и вовлекать представителей бизнеса, широко используемых на рынке fast moving consumer goods. Рекомендуется придать данным программам имиджевый республиканский характер для создания резонансной узнаваемости и использования. В работе проведен анализ осведомленности, вовлеченности местного населения в вопросы экологической переработки и утилизации отходов на основе онлайн-опроса, а также представлена сводная программа мотивации населения. Авторами рассматриваются предпосылки внедрения данных программ, их основные характеристики, цели и показатели эффективности.

Ключевые слова: сортировка мусора, переработка отходов, зеленая экономика, мотивационная программа, экология.

\section{Introduction}

One of the main factors of environmental pollution is the activities of cities. The growth of the population, industrial economy leads to an increase in waste, while the problems of their disposal are destructive for the global ecosystem - this is soil pollution during waste disposal, air pollution with highly toxic compounds during waste incineration, and degradation of ground and underground waters, which are enriched for account of residues of decomposing waste, etc. At the same time, the increasing trend towards urbanization certainly leads to an increasing trend of a constant increase in the mass of waste.

Disposal of waste can currently occur in the following ways:

- waste disposal;

- waste incineration;

- reuse of waste.

At the same time, of course, waste recycling is the most resource-saving way. Sorting garbage when using this method is key.

In Europe and the countries of East Asia, an efficient waste sorting system has been practiced for a long time, but for the CIS countries waste recycling is a new and not entirely studied trend.

In developed countries, the attitude to waste sorting is brought up from an early age, an appropriate culture of behavior, consumption has been developed, the infrastructure for special container systems for sorting waste is organically integrated not only into urban reality, but also in household use in the form of built-in sections. European countries occupy high positions in terms of environmental friendliness of the territory, with only $1 \%$ of non-recycled waste.

European countries have been moving towards the practice of sorting solid waste for about 30 years. The experience of countries such as Sweden and Japan demonstrates the benchmark and vector of development. So, Sweden is so successful in the field of waste recycling that it even makes money on waste disposal, importing it from other countries. In Sweden, $99 \%$ of household waste is recycled. This is one of the highest rates in the world. At the same time, almost half of the waste in the country is incinerated - but only after careful sorting. Plastics, paper, food waste are used for processing or biogas production. The distribution of waste work in Sweden is as follows:

- recyclable - 50.6\%,

- burned for energy production $-48.6 \%$,

- sent to landfills - 0.8\% (Rousta K., Ekström K.M., 2013) .

Turning to the Kazakh practice, we have the following figures: the total volume of accumulated solid waste in Kazakhstan is already about 100 million tons, while an average of 5-6 million tons is generated annually. According to experts' calculations, by 2025 this figure can grow to 8 million tons per year of formation. At the same time, the bulk of this waste is disposed of at landfills without additional processing, without neutralization. The rates of accumulation of solid household waste per capita by regions vary from 80 to more than $400 \mathrm{~kg}$ per year (When will the "garbage" business in Kazakhstan, 2020).

There is one law on waste processing in the country - the Law "On disposal of industrial waste and other waste in the Republic of Kazakhstan". Penalties apply for non-compliance with this law. During the quarantine period, many problems became more pronounced: people began to produce more waste, while cleaning the territories was carried out in a regular mode. In this regard, the Ministry of Ecology, Geology and Natural Resources was forced to toughen fines for exceeding the standards 
for emissions into the environment. On behalf of the head of state, the amount of the fine was increased to $20 \mathrm{MCI}$ for individuals and up to $500 \mathrm{MCI}$ for business entities (Fines for harming nature will be toughened in Kazakhstan, 2020)

In large cities of Kazakhstan, there are special bins for sorting food and solid household waste (MSW), orange containers are installed for sorting plastic, glass and iron. There are also collection points for waste paper, glass and electronic waste.

However, despite the measures taken, waste sorting in Kazakhstan is ineffective largely due to the lack of environmental education. The most pronounced manifestations of environmental ignorance are manifested as follows:

a) People do not use special waste bins for sorting garbage. not particularly aware of their operational differentiation;

b) In addition to the fact that there are not enough collection points for secondary raw materials, many townspeople do not know about their existence;

c) Local townspeople are currently at the initial stage of developing a culture of sorting garbage and for them material interest is extremely important at this stage. However, local points offer fairly low waste rates. For example, $1 \mathrm{~kg}$ of waste paper is estimated at 20-30 tenge (this is about 0.05-0.07 dollars per kg.), Which does not even allow to cover travel on public transport, if the collection point is far away.
Thus, we can say that the population of Kazakhstan is not yet ready to move to a new stage in the development of the ecosystem.

\section{Materials and methods}

Both qualitative and quantitative methods of analysis were used to analyze the improvement in the efficiency of the waste sorting system in Kazakhstan.

The analysis used methods such as:

- marketing research - a survey of the population of the city of Almaty was carried out;

- system analysis - a review of incentive programs in other countries was made, on the basis of which a motivational program of activities was proposed;

- comparative analysis - an analysis of the performance indicators of the waste sorting system in other countries is presented.

The online survey was conducted among Almaty residents aged 18-55 using the Google Forms platform from November 25 to December 25, 2020. The sample consisted of 940 people, the survey consisted of 6 questions, among which there were questions of both open and closed types.

The survey included questions about awareness in the use of waste sorting infrastructure, about the experience of interaction with local companies for the collection of recyclable materials and, in general, about the public's concern about environmental problems associated with increased consumption, mass of waste

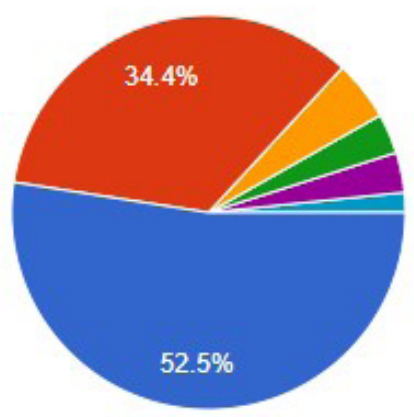

в организованные мусорные контейнеры у дома/ Into organized d...

в урны во дворе/ in the urns in the yard

использую раздельные контейнеры для разного вида мусора/ I use sepa..

сдаю макулатуру, бутылки итд в пункты приема/ I hand over waste pa...

Если есть поблизости специальные раздельные организованные урны и..

Мы их сжигаем

Figure 1 - Waste collection methods in Kazakhstan based on survey data (compiled by the author) 
During the survey, the following results were obtained:

- $84.5 \%$ of respondents do not use the practice of separate collection and sorting of waste;

- $48.9 \%$ of respondents are not aware, do not know what types of special waste containers for what type of recyclable materials are intended;
- $56.3 \%$ of respondents have never handed over recyclable materials to specialized collection points for recyclable materials (see Figure 2).

Thus, the survey revealed extremely low indicators of environmental education in Almaty, which is one of the most developed cities in the country.

\section{Как часто Вы сдаете вторичное сырье (макулатуру, стекло, пластик итд) в компании по сбору вторичного сырья?/ How often do you hand over recycled materials (waste paper, glass, plastic, etc.) to a recycling company?}

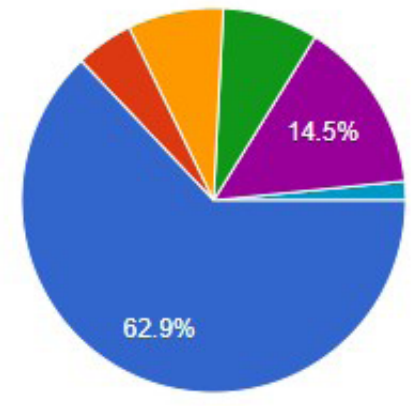

Picture 2 - Frequency of recyclable materials delivery by Kazakhstani citizens to specialized waste recycling centers (compiled by the author)
Systematic and comparative analyzes made it possible to present the processed information in the form of a consolidated table as a comprehensive program to motivate the population to separate waste collection.

\section{Literature review}

Garbage is a great resource in the wrong place lacking someone's imagination to recycle it into everyone's benefit (Hansen 2015). Waste problems attract the global attention among conservationists, scientists and common citizens.

Waste can mean many things to different people Some people, in most of them developed economies, consider garbage as an additional way to obtain new resources, energy, and income. And other people, mainly in developing countries, see garbage as an urgent problem that needs to be addressed. (Moore, 2012). The level of education and awareness of effective waste management practices is essential in this gap (Milea, 2009; O'Connell, 2011).
The next in priority of the existing reasons for the increase in waste in public places can be considered the lack of effective penalties, as well as the lack of social pressure and responsibility (Al-Khatib et al., 2009).

An irrelevant priority in solving waste sorting problems is the convenience of garbage cans - if there are none, then there is no garbage sorting, respectively (Henry et al., 2006).

The fact of the persistent habit of throwing garbage on the streets, which is generated by the lack of ecological culture in society, cannot be excluded from the reasons, which is why in such societies it is so difficult and long to change consumer behavior and remove this habit from everyday life (Yusif and Scott, 2007).

According to Tucker (Tucker, P., 2001), Barr (Barr S., 2002) and Madden et al. (Madden, T.J., 1992), behavioral aspects such as intention are critical to effective waste separation activities. Scientists also highlight factors such as motivation, cultural aspects. (Weinreich, P., 2009). 
A major obstacle in the developing world is the lack of awareness of effective waste management practices. This low awareness generates a lack of interest and initiative in waste management (Bolaane, 2006). Indifference to environmental issues creates a culture of non-participation of the entire community in effective decision-making processes (Poswa, 2001).

Researchers widely recognize the need to raise public awareness of waste sorting and recycling in order to form ecological citizenship in the world (Lumbreras Martín and Fernández Garca, 2014).

As O'Connell (O'Connell, 2011) has stated, attitudes towards disposal are strongly influenced by "knowing where, when and how to dispose of." Research from more than twenty-two developing countries (Guerrero et al., 2013) shows that when citizens are motivated, aware of the benefits of recycling and how to sort waste, they participate in recycling campaigns. Social norms also play an important role in shaping behavioral characteristics when participating in processing activities. People are more likely to recycle when they regularly observe similar processes in the community, which is why it is so important to reach out to local opinion leaders to change negative environmental behavior (O’Connell, 2011).

According to EPA (EPA, 2015), waste minimization is the process of eliminating and reducing the mass of waste generated in a society, which helps eliminate the generation of harmful and waste, while supporting efforts to create a more sustainable society. Waste minimization involves recycling products and / or changing social patterns of consumption and production to prevent waste generation.

\section{Discussion and Results}

After analyzing the experience of advanced countries in teaching people to separate waste collection, the authors propose a motivation program for consideration (see Table 1).

Table 1 - The program of motivating the population of Kazakhstan for separate waste collection (compiled by the author)

\begin{tabular}{|c|c|c|c|}
\hline Type of event & Name of event & Description & Market participants involved \\
\hline \multirow{3}{*}{$\begin{array}{l}\text { Image and } \\
\text { educational } \\
\text { events }\end{array}$} & $\begin{array}{l}\text { championships / } \\
\text { marathons in sport } \\
\text { garbage collection }\end{array}$ & $\begin{array}{l}\text { a competition in which students, } \\
\text { social activists, employees of oil } \\
\text { industry enterprises and environmental } \\
\text { organizations take part }\end{array}$ & $\begin{array}{l}\text { Corporate foundations that are } \\
\text { organizers of port marathons } \\
\text { in cities (for example, «Almaty } \\
\text { Marathon») }\end{array}$ \\
\hline & Learning application & $\begin{array}{l}\text { Explanatory application based on } \\
\text { frequently used as an additional section }\end{array}$ & 2gis, Onay, CityBus, Kaspi.kz etc \\
\hline & Outdoor advertising & $\begin{array}{l}\text { Explanatory posters, billboards, posters } \\
\text { under the auspices of state social } \\
\text { advertising }\end{array}$ & $\begin{array}{l}\text { Places of mass gathering: metro, bus } \\
\text { stops, shopping centers, etc. }\end{array}$ \\
\hline \multirow{2}{*}{$\begin{array}{l}\text { Events at Sales } \\
\text { Points }\end{array}$} & $\begin{array}{l}\text { Repair, acceptance } \\
\text { of outdated, outdated } \\
\text { equipment }\end{array}$ & $\begin{array}{l}\text { Provision of discounts on goods on a } \\
\text { funded system, provision of services for } \\
\text { the repair of equipment, exchange }\end{array}$ & $\begin{array}{l}\text { Market leaders in the sale of } \\
\text { electronics and household } \\
\text { appliances, points for repair, } \\
\text { processing. }\end{array}$ \\
\hline & $\begin{array}{l}\text { Installation of devices for } \\
\text { receiving batteries and } \\
\text { light bulbs }\end{array}$ & $\begin{array}{l}\text { Provision of discounts for goods on a } \\
\text { funded system }\end{array}$ & $\begin{array}{l}\text { Market leaders in the sale of } \\
\text { electronics and household } \\
\text { appliances. }\end{array}$ \\
\hline \multirow{3}{*}{$\begin{array}{l}\text { Events at Sales } \\
\text { Points }\end{array}$} & $\begin{array}{l}\text { Acceptance from buyers } \\
\text { of leftover building } \\
\text { materials, paint }\end{array}$ & $\begin{array}{l}\text { Provision of discounts for goods on a } \\
\text { funded system }\end{array}$ & $\begin{array}{l}\text { Points of organized sale of building } \\
\text { materials }\end{array}$ \\
\hline & $\begin{array}{l}\text { Acceptance of old shoes } \\
\text { in exchange for discount } \\
\text { coupons }\end{array}$ & $\begin{array}{l}\text { Cooperation with charitable } \\
\text { organizations, second-hand organizations, } \\
\text { orphanages, rubber waste recycling } \\
\text { plants for the production of coatings } \\
\text { for stadiums, courts and playgrounds, } \\
\text { providing discounts on goods through a } \\
\text { funded system }\end{array}$ & Shoe stores, chain stores \\
\hline & $\begin{array}{l}\text { Reduce the sale of plastic } \\
\text { bags by at least } 50 \% \\
\text { with the sale of reusable } \\
\text { shopping bags }\end{array}$ & $\begin{array}{l}\text { When buying goods over the indicated } \\
\text { amount, a reusable shopping bag is a gift }\end{array}$ & Retail network \\
\hline
\end{tabular}


Continuation of table 1

\begin{tabular}{|l|l|l|l|}
\hline \multicolumn{1}{|c|}{ Type of event } & \multicolumn{1}{|c|}{ Name of event } & \multicolumn{1}{|c|}{ Description } & \multicolumn{1}{c|}{ Market participants involved } \\
\hline $\begin{array}{l}\text { Activities for } \\
\text { organizing } \\
\text { space for } \\
\text { sorting garbage } \\
\text { at home }\end{array}$ & $\begin{array}{l}\text { Selling a convenient } \\
\text { stylish low-cost multi- } \\
\text { compartment waste } \\
\text { storage system }\end{array}$ & $\begin{array}{l}\text { Sale, accompanied by an active } \\
\text { introductory advertising campaign, taking } \\
\text { into account government support for the } \\
\text { use of multi-section waste collection } \\
\text { systems }\end{array}$ & $\begin{array}{l}\text { Zeta, specialized points of sale by } \\
\text { storage systems }\end{array}$ \\
\cline { 2 - 5 } & $\begin{array}{l}\text { Built-in space in the } \\
\text { kitchen for organizing } \\
\text { separate waste collection }\end{array}$ & $\begin{array}{l}\text { Planning, kitchen design, taking into } \\
\text { account the built-in space for organizing } \\
\text { separate waste collection }\end{array}$ & $\begin{array}{l}\text { Furniture manufacturing, assembly } \\
\text { companies, design schools, } \\
\text { developers }\end{array}$ \\
\hline $\begin{array}{l}\text { Activities } \\
\text { in school, } \\
\text { preschool } \\
\text { institutions }\end{array}$ & $\begin{array}{l}\text { Introduction of the } \\
\text { compulsory subject } \\
\text { «Garbage processing» }\end{array}$ & $\begin{array}{l}\text { Introducing children to the basics of } \\
\text { environmental education from an early } \\
\text { age }\end{array}$ & $\begin{array}{l}\text { Kindergartens, schools, preparatory } \\
\text { courses }\end{array}$ \\
\hline
\end{tabular}

These measures are proposed to be considered as a whole, since individually, each of them is only fragmentary measures that are not highly effective individually, while a set of measures can have a systemic effect.

The proposed image, educational events (championships and applications), of course, should have a resonant effect, which is valid for some time, but immediately after which specific product solutions should be proposed that encourage consumers to take immediate action, i.e. consolidate the obtained image effect in practice ... These include events in different segments of consumer markets. For each of the proposed activities in points of sale, the key motivating factor is the introduction of a discount / bonus accumulation system. To implement this system, you may need either a separately allocated bonus card linked to the application, or any valid bonus cards in specific retail chains - participants in the incentive program.

The authors propose to fix the following pilot values as the main threshold values for bonuses / points:

- for $1 \mathrm{~kg}$ of plastic or paper -600 points per card

- $1 \mathrm{~kg}$ of glass -150 points

- $1 \mathrm{~kg}$ of metal -700 points

At the end of the reporting period, points are converted into bonuses that can be used for purchases in retail chains participating in the incentive program. When transferring to bonuses: 100 points $=10$ tenge. This bonus scheme may be considered a test one and will change depending on the results of the pilot period.

According to a survey conducted by the author, more than $60 \%$ of respondents would use such a motivation system (see Fig. 3).

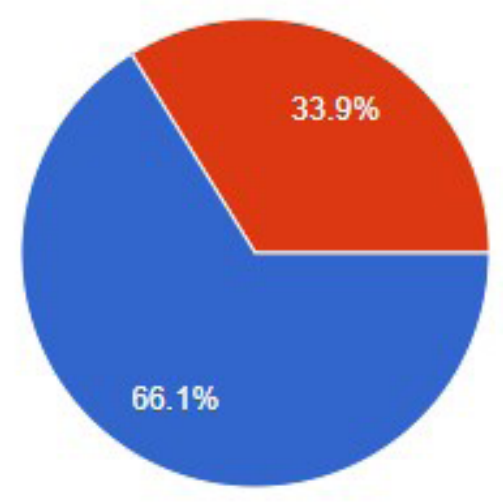

Да / Yes

Het / No

Figure 3 - Willingness of residents of Almaty to participate in the bonus campaign upon delivery of recyclable materials (compiled by the author) 
Thus, we can state the fact that the local population is optimistic about motivational programs, and the initiatives already introduced can provide a good basis for progress in solving the problem of separate waste collection. But the main problems to this day remain the low awareness of citizens in the issue of environmental education. With a systematic approach to this issue, the effective involvement of market participants, the state and citizens themselves, this problem, taking into account the experience of other countries, can be solved in a faster time frame and turned into resources.

\section{Conclusion}

The current waste situation in Kazakhstan should be seen not as a problem, but as an opportunity. If a culture of waste sorting is systematically fostered in people, this will generally change the culture of society. Through integrated systemic holistic programs, a habit of separate waste collection should be formed in society. These factors are paramount, but their implementation requires patient step-by-step implementation of all the classic success factors of project management and social marketing. Of course, the state should support such projects, otherwise the full effect cannot be expected. It is necessary to conduct image and educational events, actions on a regular basis, but always with the subsequent support of proactive events involving the maximum number of business participants.

At this intermediate stage, it is necessary to encourage as much as possible, everywhere continue to introduce the practice of abandoning disposable bags in stores and switch to reusable fabric bags and bags, as well as all citizens to switch to conscious consumption with the correct presentation of opinion leaders, introducing this trend into the rank of fashion trends.

\section{References}

Al-Khatib, I. A., Arafat, H. A., Daoud, R., and Shwahneh, H. (2009). Enhanced solid waste management by understanding the effects of gender, income, marital status, and religious convictions on attitudes and practices related to street littering in Nablus Palestinian territory. Waste Management, 29(1), 449-455.

Barr, S. Household Waste in Social Perspective: Values, Attitudes, Situation and Behaviour; Ashgate: Burlington, VT, USA, 2002.

Bolaane, B. (2006). Constraints to promoting people centred approaches in recycling. Habitat International, 30(4), 731-740.

EPA. Waste Minimization Opportunity Assessment Manual. (1988). Retrieved February10, 2015. http://yosemite.epa.gov/water/ owrccatalog.nsf / 9da 204a4b4406 ef 885256ae0007a79c7/f6c1111e08becee585256b0600725832!OpenDocument.

Fines for harming nature will be toughened in Kazakhstan, 22.07.2020 https://lsm.kz/minekologii-provedet-rejdy-poekologicheskim-zonam

Guerrero, L. A., Maas, G., and Hogland, W. (2013). Solid waste management challenges for cities in developing countries. Waste Management, 33(1), 220-232.

Hansen, Mark Victor. 2015. 'Mark Victor Hansen | Mark Victor Hansen.' Accessed August 28. http://markvictorhansen.com/.

Henry, R. K., Yongsheng, Z., and Jun, D. (2006). Municipal solid waste management challenges in developing countries - Kenyan case study. Waste Management, 26(1), 92-100.

Lumbreras Marthn, J., and Fernбndez Garcha, L. (2014). Comprehensive solid waste management: The Ciudad Saludable model in Peru. Retrieved February 10, 2015. http://idbdocs.iadb.org/wsdocs/getDocument.aspx?DOCNUM=39168981.

Madden, T.J.; Ellen, P.S.; Ajzen, I. A Comparison of the Theory of Planned Behaviour and the Theory of Reasoned Action. Personal. Soc. Psychol. Bull. 1992, 18, 3-9.

Moore, S. A. (2012). Garbage matters: Concepts in new geographies of waste. Progress in Human Geography, 36(6), $780-799$.

O'Connell, E. J. (2011). Increasing public participation in municipal solid waste reduction. Geographical Bulletin, 52(2), $105-118$.

Olander, F.; Thwgersen, J. Understanding of consumer behaviour as a prerequisite for environmental protection. J. Consum. Policy 1995, 18, 345-385. [CrossRef]

Poswa, T.T. (2001). A comparison of attitudes towards and practices of waste management in three different socio-economic residential areas of Umtata. Published Master's Thesis, Durban University of Technology, KwaZulu-Natal, South Africa.

Rousta K, Ekström K.M, (2013) Assessing Incorrect Household Waste Sorting in a Medium-Sized Swedish City. Sustainability 5(10): 4349-4361

Tucker, P. Understanding recycling behaviour. Paper Technol. 2001, 42, 51-54.

Weinreich, P. 'Enculturation', not 'acculturation': Conceptualising and assessing identity processes in migrant communities. Int. J. Intercult. Relat. 2009, 33, 124-139. [CrossRef]

Yousif, D. F., and Scott, S. (2007). Governing solid waste management in Mazatenango, Guatemala. International Development Planning Review, 29(4), 433-450. 